О. И. Гамали, Л. А. Ярош

\title{
ОТРАЖЕНИЕ МОЛОДЕЖНОЙ РЕЧИ В «ГЛЯНЦЕВОЙ» ПРЕССЕ
}

Гамалі О. І., Ярош Л. О. Віддзеркалення молодіжного мовлення у «глянцевій» пресі.

У статті розглянуто ознаки молодіжного мовлення, зокрема креативність, економність, різноманітність, ігровий характер, розпливчатість семантики тощо, що віддзеркалені в мові глянцевих журналів через різноманітні види мовної гри: фонетичні, графічні, словотвірні, лексичні, метатекстові тощо.

Ключові слова: глянцевий журнал, молодіжне мовлення, мовна гра.

Гамали О. И., Ярош Л. А. Отражение молодежной речи в «Глянцевой» прессе.

В статье рассматриваются черты молодежной речи, в частности креативность, экономность, разнообразие, игровой характер, расплывчатость семантики, отражающиеся в языке глянцевых журналов посредством разнообразных видов языковой игры: фонетических, графических, словообразовательных, лексических, метатекстовых.

Ключевые слова: глянцевый журнал, молодежная речь, языковая игра. magazines.

Hamali O. I., Yarosh L. O. Reflection of youth slang in the language of the glossy

The article gives a broad outline of youth slang and its most essential features including creativity, language economy, diversity, language play, semantic ambiguity () О. И. Гамали, Л. А. Ярош, 2015. 
reflected in the language of the glossy magazines and realized via a variety of language play, in particular, phonetic, graphic, word forming, lexical and metatextual.

Key words: glossy magazines, youth slang, language play.

Рубеж XX и XXI столетий ознаменовался серьезными трансформациями общественно-политической, экономической, идеологической жизни на постсоветском пространстве. Существование в новых реалиях требует новых людей: с новыми целями, системой ценностей, чертами характера. Формированием активного человека с современными взглядами на жизнь, стремящегося к карьерному успеху, к соответствию высоким стандартам, идеологи занимаются планомерно и целенаправленно, в том числе через средства массовой информации. Успеху такого воздействия, в частности, способствует изменение манеры ведения заочного диалога с назидательной на непринужденную, более привычную для молодых.

Цель работы - описать особенности отражения молодежной речи в таком феномене современной печати, как глянцевые журналы.

С конца XX века начался процесс активного распространения массовой прессы, женских журналов, исторически возникших в противовес политическим изданиям: «...человек подвергался прессингу негативных новостей, а глянцевый журнал обладал большой отвлекающей силой, уводящей человека от серьезных социальных проблем» [2, с. 1].

«В обиходе русского языка достаточно прочно закрепилось понятие глянцевый журнал» [4, с. 170]. Глянцевые журналы всего за несколько десятков лет успели стать «ярчайшими атрибутами цивилизации, их «красочным» отражением» [15, с. 99]. Этот феномен преимущественно исследовался философами и культурологами (В. Буряковская, М. Войченко, М. Гудкова, В. Смеюха, И. Тортунова и др.). Языковые особенности «глянца» практически не изучены.

Чертами, позволяющими квалифицировать журнал как глянцевый, являются: высочайшее полиграфическое качество; равноправное сосуществование визуального и вербального материала; расчет на конкретную возрастную, интеллектуальную и гендерную аудиторию; широкий тематический спектр, рассчитанный на отдых читателя (что создает «иллюзию вечного праздника жизни») [14, с. 2].

Бесспорно, что язык глянцевой периодики обладает всеми характеристиками публицистического стиля, причем публицистического стиля наших дней, отмеченными, «собранными» многими лингвистами 
(В. Буряковская, Э. Вишняков, Т. Гриценко, Т. Дмитрова, Н. Клушина и др.): - оценочностью, чаще скрытой, т. к. «на смену пропаганде пришло завуалированное манипулирование массовым сознанием» [11, с. 161]);

- эмоциональностью и экспрессивностью, поскольку «...лингвистически релевантной характеристикой массовой литературы является гипертрофия эмоционального компонента и редукция рационального» $[2$, с. 4$])$;

- образностью изложения материала, широчайшим использованием всех видов тропов;

- доступностью языковых средств и формулировок, ориентированных на широкий круг потребителей;

- экономией языкового материала (лаконичностью изложения при информативной насыщенности);

- широким проявлением авторской индивидуальности, что демонстрирует «современную установку средств массовой информации на творчество, а не на стереотип» [2, с. 289]);

- изложением нестандартными средствами [6, с. 51];

- переосмыслением фразеологии, лексики других стилей и терминологии в целях публицистики [7, с. 2];

- интертекстуальностью, создающей вертикальный контекст, усложняющий речевое произведение журналиста [9, с. 120];

- восприимчивостью к новым экспрессивным языковым явлениям, зарождающимися в разговорной речи $[12$, с. 2$]$.

Большинство глянцевых журналов адресовано молодежи, играющей важную роль в жизни общества: «именно представители молодого поколения отличаются стремлением ко всему новому, способностью моментально реагировать на все происходящее вокруг, уверенностью $и$ «безоглядностью», что делает их поступки и действия решительными, смельми, бескомпромиссными» [8, с. 1]. Эти психологические особенности ярко отражаются в языке молодежи - явлении неоднородном, сочетающем в себе различные языковые феномены, формирующие молодежный дискурс - «конгломерат собственно лингвистических, социолингвистических, лингвокультурологических факторов, дающих представление о единой когнитивной концептосфере» [1, с. 2].

В начале XXI века русская молодежная речь сочетает в себе специфический сленг, уходящий корнями в основные формы существования русского языка (кодифицированный литературный язык, разговорная речь, территориальные диалекты), второстепенные формы существования русского языка (уголовное и офенские арго, корпоративные ○ О. И. Гамали, Л. А. Ярош, 2015. 
и профессиональные жаргоны) и иностранные языки (английский, древнееврейский, цыганский и пр.) [13, с. 30]. Активизации заимствований, особенно англицизмов, способствуют представление об экзотичности, престижности владения иностранными языками, влияние на речь СМИ, увлечение современной музыкой и компьютерными играми.

Речь молодежи - явление противоречивое: с одной стороны, наблюдается тенденция к использованию сниженных элементов, с другой активизируется языковая игра, рассчитанная на высокий интеллектуальный уровень собеседника, высвобождающая заложенные в языке экспрессивные возможности. «Язык для молодых людей во многом является средством развлечения, забавы: словесная игра обусловлена интересом к собственному языку, проверкой его возможностей и скрытых ресурсов; язык - тот игровой материал, который приносит удовлетворение лишь тогда, когда есть возможность уйти от привычного» [5, с. 5].

Необходимость выражать большое количество информации минимальными языковыми средствами приводит к появлению многозначности слов, явлению энантиосемии; частотными являются процессы усечения и универбации. Креативность молодых выражается в речетворчестве - в индивидуально-авторских значениях и окказионализмах [12]. Таким образом, главными характеристиками молодежного языка становятся: первобытность, проявляющаяся в макаронизме; креативность; расплывчатость семантики, «атавистический примитивизм»; экономность; изменчивость; игровой характер.

Анализ материалов журналов «Glamour», «ELLE», «MINI», «Pink», «Vogue», «Joy», «Cosmopolitan», «Л'Этуаль» за 2012-2015 годы показал, что их издатели преимущественно ориентируются на особенности молодежного общения, поддерживающие позитивный имидж молодого человека: поддерживаются креативность и игровой характер, в то время как первобытность и примитивизм подчеркиваются значительно реже.

Креативность проявляется в активном образовании окказионализмов, изменении фонетического облика слов, замещение в морфемном составе.

Окказионализмы имеют прозрачную внутреннюю форму. Например, название статьи «Мехопанорама» образуется путем сложения слова мех ('выделанная шкура пушного зверя несколько таких шкур, сшитые вместе' (3, с. 347) и панорама ('широкий обзор каких-либо современных явлений, фактов, событий в прессе, кино и т.п.' (3, с. 94): «Пушистый натуральный или экомех этой зимой может быть в моде; ЈОY выбрал необычные аксессуары и вещи с меховой отделкой». 
(Добавим также, что окказионализм перекликается с названием одиозной юмористической телепрограммы «Смехопанорама».)

Минимальное изменение фонетического облика слова бронежилет - 'пуленепробиваемый бронированный жилет' (3, с. 56) - превращает его в бронежеле в статье о том, что ««Князь тьмы»», как его называют фанаты, ведет образ жизни скромного аутиста: ни дебошей, ни съеденных жен за ним не числится. Единственный каприз-мармеладные мишки: эти конфеты всегда лежат в его гримерке». Трансформация подчеркивает любовь рокера к желе - 'сладкому студенистому кушанью, готовящемуся с помощью желатина из фруктово-ягодных соков, вина, молока и других продуктов' (3, с. 187).

Слово сахарозаменители используется как производное от существительного Сахара (крупнейшая на земле пустыня, расположенная в Северной Африке), а не от сахар ('пищевой продукт, кристаллическое сладкое вещество...') (3, с. 720).

Заметка о том, что «Приятная новость ожидает тех, кто иногда не прочь побаловать себя сладким: теперь можно попробовать на вкус торт с воздушной бисквитной основой и нежным кремом, изготовленным из сливок и натурального бельгийского шоколада высокого качества» называется «Шокотерапия». При этом предполагается образование этого слова сложением шок- (часть слова шоколад) и существительного терапия. Значением термина шокотерапия - 'метод психиатрического лечения, при котором вызывается эпилептический припадок посредством пропускания электрического тока через мозг пациента', пренебрегают.

Экономность достигается усечением слов и словосочетаний.

Так, сокращен компонентный состав фразеологизма ходить вокруг да около до вокруг да около в статье о правилах нанесения средств по уходу за кожей вокруг глаз. При этом фразеологическое значение 'говорить намеками, иносказательно' (5, с. 509) заменяется суммой значений компонентов вокруг - 'кругом, во все стороны' $(3$, с. 89$)$ и около - 'возле, рядом' (3, с. 449).

В названии журнальной статьи «Во все тяжкие» использован усеченный фразеологизм пуститься во все тяжкие - 'безудержно предаваться чему-либо предосудительному’ (5, с. 371) и актуализировано значение прилагательного тяжкий - 'грузный, лишенный легкости' (6, с. 656): «Главная героиня модного сезона - самоуверенная оторва; стать такой помогут аксессуары и одежда из черной кожи».

Разнообразие выражается в отсылке к прецедентным феноменам из различных областей знания: 1) литературы: «Барышня-крестьянка», ○ О. И. Гамали, Л. А. Ярош, 2015. $-258-$ 
«Война и мир», "Дворянское гнездо», "Красное и черное», «Мамама Кураж», «Человек в футляре» и др.; 2) библейских текстов: «Нагорная проповедь», «И последние станут первыми», «По образу и подобию» и др.; 3) скульптуры: «Девушкам с веслом»; 4) киноиндустрии и телевидения: «Клуб находчивых», «Пусть говорят», «Царь горы», «Красота поамерикански», «По воле рока так случилось» и др.; 5) музыки: «Голая рядом», «На поле панки грохотали», «Легко уладить с помощью финта» и др.; 6) истории: освободительное движение, форма правления, культ личности, крестовый поход и др.; 7) психологии: образное мышление, шоковая терапия, раздвоение личности и др.; 8) экономики: полная занятость, движимое имущество, прожиточный минимум, ворс-мажсо; 9) образования: класс коррекиии, ученая степень и др.; 10) географии и биологии: эффект бабочки, подводное течение, радужная оболочка, строение клетки и др.; 11) химии, физики: органическая химия, электрический заряд, короткое замыкание, элементарная частица и др.; 12) математики: описывать окружность, плюс на минус и др.; 13) астрономии: солнечная система, Теория большого взрыва.

Игровой характер очевиден, поскольку язык для молодых людей во многом является средством развлечения, забавы, игровым материалом, который приносит удовлетворение тогда, когда есть возможность уйти от привычного. Игра возможна на различных языковых уровнях:

1) фонетическом (звукоподражания «U-u-u»» $u \ll T-c-c »$, которые используются как названия рубрик, где информация передается читательницам «по секрету»);

2) графическом (написание компонента ПАРА прописными буквами в названии статьи «ПАРА-нормальное явление». Выделенный компонент становится смыслообразующим: napa - 'два существа, находящиеся вместе, объединенные чем-либо общим, рассматриваемые как нечто целое', а в статье речь идет о том, что «по примеру знаменитостей вы уже научились сочетать платье с костюмом бойфренда? Пора приобрести родство души и в гармонии парньх ароматов»);

3) лексическо-фразеологическом (нетрадиционное использование фразеологизмов и терминов): статья об исчезновении рекламы алкоголя со страниц журналов названа «Последняя капля»; фразеологизм со значением 'то, что переполняет чашу терпения, о повторяющихся ошибках и неверных действиях превращается в свободное словосочетание с актуализированными значениями каждого компонента: последний - 'конечный в ряду чего-либо' и капля - 'маленькая отдельная частица жидкости округлой формы';

-259- О. И. Гамали, Л. А. Ярош, 2015. 
4) метатекстовом (обыгрывание прецедентных феноменов: имен, текстов, высказываний, ситуаций): часто цитируются различные строки песни В. Шаинского на слова М. Пляцковского «Улыбка». К примеру, статья о кампании \#мореульббок - против злобы, зависти и агрессии в интернете («Не поддавайтесь соблазну оставить недружелюбный комментарий под чьим-то постом, поставьте лайк фотографии всеобщая карма улучшится») озаглавливается строкой «От ульљки станет день светлей». Другая строчка из этой же песни («Радуга проснется») используется в статье о кружевном белье карамельных цветов (на основе главного признака радуги - разноцветности). Прецедентное высказывание «Станет всем теплей» употребляется в статье о том, что «...подобрать головной убор, который гармонично завериит образ, сегодня не составит труда: гимназистки обожали муфты, потому что в них можно было прятать любовные послания». В основе этой языковой игры лежит многозначность существительного тепло (и однокоренного наречия): в оригинальной фразе из песни тепло - 'сердечность, доброта, ласка; сердечное отношение к кому-либо' $(3$, с. 826$)$, а в названии статьи тепло - 'ощущение согревания' $(3$, с. 826$)$.

Расплывчатость семантики, «атавистический примитивизм» выражаются в характерном для молодых использовании малознакомых, но «ярких» слов и выражений в неправильных, искаженных значениях.

Так, формой правления - это «элемент формы государства, который предопределяет систему организации высших органов государственной власти, порядок их образования, сроки деятельности и компетенцию» [10, с. 121]. В статье с названием «Форма правления» речь идет о формах - 'внешних очертаниях, наружном виде' (3, с. 895) - одежды в коллекции Chanel весна-лето 2013: «...это объемные силуэты и акцентированная линия плеча, привет 80-м и внимание к деталям».

Термином ученая степень - ступень квалификационной системы в науке, позволяющая ранжировать ученых и их достижения - в журнальной статье озаглавлена заметка о том, что, «если вечеринкам она предпочитает тихий вечер в компании Флобера или Шопенгауэра - не вздумайте дарить книгу, она наверняка у нее уже есть». Актуализируется разговорнопренебрежительное значение прилагательного ученыц - 'слишком умный, мудреный, замысловатый' (3, с. 884).

Статья с названием «Как произносить свадебные тостыл» рекомендует читателям не «растекаться мыслью по древу». Энциклопедический словарь крылатых слов и выражений отмечает, что неверно переведенная строка из «Слова о полку Игореве» в современном ○ О. И. Гамали, Л. А. Ярош, 2015. 
русском языке живет своей, самостоятельной жизнью. В «Слове» сказано: «Боян вещий, если кому-то хотел сложить песнь, растекался мысию по дереву, серым волком по земле, сизым орлом под облаками». Мысь в переводе со старославянского 'белка'. Соответственно, автор говорит, что Боян, слагая песнь, охватывал мысленным взором весь мир: бегал белкою по дереву, серым волком - по земле, летал орлом под облаками. В современном понимании данная фраза означает 'вдаваться в ненужные подробности, отвлекаться от основной мысли, затрагивать разные побочные, подобно ветвям дерева, темы' (7).

Даже поверхностный анализ языка глянцевых журналов обнаруживает его ярко выраженный креативно-игровой характер, ориентированный на молодежное восприятие и обусловленный целым комплексом функций: аттрактивной, развлекательной, эвфемистической, людической (создание привлекательной языковой формы). Читатель, способный принять участие в предложенной языковой игре - дешифровке преобразований на различных языковых уровнях, вольно или невольно вовлекается в освоение современной национальной системы ценностей и антиценностей, поскольку, какие бы темы ни поднимались (мода, здоровье, еда, спорт и т. п.), для их освещения используются отсылки к широкому набору общественно значимых текстов - от классических до современных, от художественных до научных, от собственно вербальных до креолизованных. Чтобы до конца понять язык «глянца», необходимо владеть традиционным набором прецедентных феноменов. Заметим, что языковая игра становится одним из средств комически-иронического окрашивания «глянцевого» текста, что открывает новые аспекты его дальнейшего исследования.

\section{Литература}

1. Атаева Е. В. О функционировании дискурсивных слов в речи молодежи [Электронный pecypc]/ Е. В. Атаева, Д. С. Малышева. - Режим доступа : http://www.isuct.ru

2. Буряковская В.А. Глянцевый журнал как феномен массовой культуры: речевое и прагматическое представление [Электронный ресурс] / В. А. Буряковская. Режим доступа : http://cyberleninka.ru

3. Вишняков Э. А. Языковые особенности газетно-публицистического стиля Испании [Электронный ресурс]/Э. А. Вишняков. - Режим доступа : http://www.pglu.ru

4. Войченко В. М. Заголовки женских глянцевых журналов как материал для создания речевого портрета современной женщины [Электронный pecypc] / В. М. Войченко. - Режим доступа : http://cyberleninka.ru

5. Волохова В. В. Особенности разговорного языка немецкой и российской -261- ○ О. И. Гамали, Л. А. Ярош, 2015. 
молодежи [Электронный pecypc]/ В. В. Волохова. - Режим доступа : http://www.rusnauka.com

6. Гриценко Т. Б. Українська мова за професійним спрямуванням [Электронный pecypc] / Т. Б. Гриценко. - Режим доступа : http://p-for.com

7. Дмитрова Т. В. Особливості газетно-публіцистичного стилю як системи функціонування суспільно-політичних мовних жанрів [Электронный pecypc] / Т. В. Дмитрова, I. В. Камінська. - Режим доступу : http://intkonf.org

8. Дуарова А. А. Особенности разговорной речи современной молодежи [Электронный ресурс] / А. А. Дронова. - Режим доступа : https://www.google.com.ua

9. Земская Е. А. Цитация и виды ее трансформации в заголовках современных газет [Электронный ресурс] / Е. А. Земская. - Режим доступа : http://evartist.narod.ru

10. Иванов В. Формы правления и политического режима: в поисках нового содержания [Электронный ресурс]/ В. Иванов. - Режим доступа : http://www.intelros.ru

11. Клушина Н. И. Общие особенности публицистического стиля [Электронный pecypc] / Н. И. Клушина. - Режим доступа : http://evartist.narod.ru

12. Копытина Н. Н. Лингвистические особенности современного французского молодежного социолекта [Электронный ресурс] / Н. Н. Копытина. - Режим доступа : http://dspace.bsu.edu.ru

13. Муравьева Н. Г. Понятие социокультурной компетенции в современной науке и образовательной практике [Электронный ресурс]/ Н. Г. Муравьева. - Режим доступа : http://www.utmn.ru

14. Ромах О.В.Глянцевый журнал как жанр современной массовой культуры [Электронный peсурс]/ О. В. Ромах, А. А. Слепцова. - Режим доступа : http://cyberleninka.ru

15. Смеюха В. В. Особенности развития глянцевых женских журналов [Электронный pecypc] / В. В. Смеюха. - Режим доступа : http://www.vestnik.vsu.ru

\section{Список источников фактического материала}

1. Белякова A. A. GLAMOUR / А. А. Белякова // Condé Nast. - 2012 - 2015.

2. Бойко У. Pink / У. Бойко // KP Media. - 2010.

3. Кузнецов С. А. Современный толковый словарь русского языка / С. А. Кузнецов. - СПб : Норинт, 2004. -959 с.

4. Мелерович М. В. Фразеологизмы в русской речи / А. М. Мелерович, В. М. Мокиенко. - М. : Русские словари, Астрель, 2001. - 856 с.

5. Орленко Л. В. Терминологический словарь одежды : около 2000 слов / Л. В. Орленко. - М. : Легпромбытиздат, 1996. - 344 с.

6. Ожегов С. И. Толковый словар русского языка / С. И. Ожегов, Н. Ю. Шведова. - М. : Индрик, 2005. -938 с.

7. Серов В. Н. Энциклопедический словарь крылатых слов и выражений / В. Н. Серов. - М. : Локид-Пресс, 2003.

8. Ткаченко О. MINI / О. Ткаченко // «Бурда-Украина». - 2013 - 2014.

9. Травинская Е. ЈОУ / Е. Травинская // «Бурда-Украина». - 2009.

10. Щедрин М. Л'Этуаль / М. Щедрин // «Первый полиграфический комбинат». 2013.

( О. И. Гамали, Л. А. Ярош, 2015.

Стаття надійшла до редакиї 25.07.2015 p. $-262-$ 